\title{
Work life balance amongst the working women in public sector banks - a case study of State Bank of India
}

\author{
Rajesh K. Yadav*, Nishant Dabhade** \\ Department of Management, RKDF College of Engineering, Bhopal (M.P.), India \\ *,**E-mail address: drrajeshkyadav@yahoo.com ,nishant.dabhade.mgmt@gmail.com
}

\begin{abstract}
In terms of Indian context, the concern over work-life balance is gradually becoming a common talk especially for women employees. Work life balance is a state of equilibrium in which the demand of both professional and personal life is equal. Each role having different set of demands and when such role demands overlap, multiple problems are faced. In reality life and work over-lap and interact. In designing the work life policies employer should think that the commitment of employees can make the difference between those companies which compete at the marketplace and those which cannot. A balanced life for women is one where they spread their energy and effort between key areas of importance. This research study aims to figure out the working environment of public sector banks for women employees and what is the perception of women about the initiative and policies of banks and effects of those initiatives on their lives. Chi square test is applied in this paper to check the authenticity of data given by the respondents. The research is conducted among working women in banks with special reference to SBI, Bhopal (M.P.) city head office. We suggest that Work-Life Balance is not a problem to be solved. It is an ongoing issue to be managed.
\end{abstract}

Keywords: Work life; Job satisfaction; working women; Social relationship; Family etc.

\section{INTRODUCTION}

Due to changes in the labor market and the changing nature of work, work-life balance is now at the top of the agenda for government and Private bodies. It is recognized that worklife balance can lead indirectly to productivity gains through increased retention and helps organizations to respond to customer needs more effectively. In any business and industrial activities it is of utmost importance to have well trained, well groomed and emotionally balanced workers available to take up employment challenges. This highlights the need among the companies to pay adequate attention to the work life balance of the workers. The arrival of globalization makes the people working across countries; as a result, concept of fixed working hours is vanishing away. Instead of just 7 or 8 a day, people are spending as much as 12-16 hours every day in office. Therefore, tension and work related pressure, responsibilities at family makes an individual difficult to find balance between work and personal life. Professional working in BPO industry, top executives, doctors, nurses, bank employees, and IT professionals are the few examples who are facing the burden of work life imbalance constantly [2]. 
Today, Industries have realized the importance of the work life balance of their employees. Organizations are setting up policies for maintaining a work life balance. They are introducing innovative methods to keep their employees happy and satisfied, as it makes office a better place to work and also impact positively on productivity. This write up tries to bring out the meaning of work life balance, their causes, their effects on organizations and the methods, systems and processes to reduce the impact of work life imbalance. [3]

\section{WHAT IS WORK LIFE BALANCE?}

Work-life balance is used to describe the equilibrium between responsibilities at work and responsibilities outside paid work; having a work-life balance means that this equilibrium is in the right position for the individual concerned. For some people it means spending more time in paid work and less time at home, while for others it means ensuring that paid work does not infringe on time needed for other responsibilities. It is about managing our work commitments with career goals, and our responsibilities at home and the wider community. Work life and personal life are inter-connected and interdependent. Work life and personal life are the two sides of the same coin. People have to make tough choices even when their work and personal life is nowhere close to equilibrium. [6, 7]

\section{STATE BANK OF INDIA - A PUBLIC SECTOR BANK}

The public banks are those banks which are directly under the control of State/Central Government. In this study State bank of India, Bhopal City (M.P.) head office and some selected branches of SBI Bhopal has taken into the account for research study purpose. The State bank of India is actively involved since 1973 in non-profit activity called Community Services Banking.

FIGURE: 1

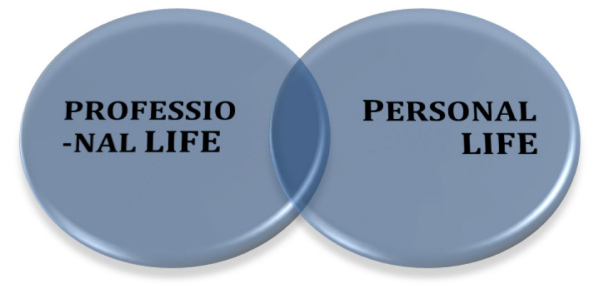

FIGURE 1: WORK LIFE IMBALANCE
FIGURE: 2

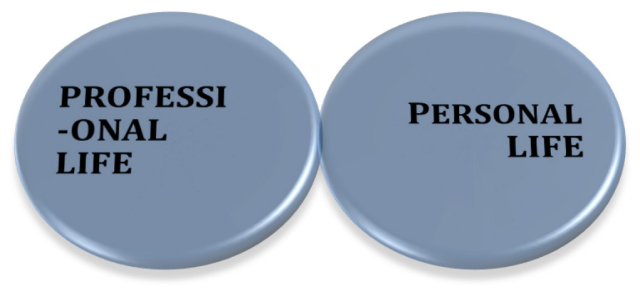

FIGURE 2: WORK LIFE BALANCE

All branches and administrative offices throughout the country sponsor and participate in large number of welfare activities and social causes. Bank's business is more than banking because we touch the lives of people anywhere in many ways. Bank's commitment to nationbuilding is complete \& comprehensive [9]. 


\section{DOES WORK LIFE BALANCE MATTERS TO EMPLOYERS AND WOMEN EMPLOYEES?}

Work-life balance policies and practices are becoming increasingly important to employers even in bank because employee's motivation and satisfaction, profitability and productivity and recruitment and retention policies can be improved by adopting flexible working arrangements. Companies have to attract and keep the best employees to remain competitive. A study conducted by (Dex and Smith, 2002) shows that [4]:

(A) There are positive effects on employee commitment from having family friendly policies.

(B) Approximately nine out of every ten establishments with some experience of these policies found them cost effectives.

(C) Increase in performance was associated with having one or other family friendly policy in the case of five out of six performance indicators.

The working sphere of Women in India is changing at incredible pace due to, progressive reduction in trade barriers, modern innovation in technologies, globally interconnected market place, cut throat competition and business rivalry and changing family and population patterns. By family pattern we mean the changing family structure from joint family to nuclear family, altered family value systems, and diminished quality time for self and children, increase in time spent on internet and altered social exchanges and communications. These factors bring out tense anxiety into the life of the women and then it is magnified many times if both the husband-wife work and they have children of growing age and old age parents. This constant worry can cause disorder on the psychological comfort of the women due to a feeling of diminished control over one's life and a hopeless perception that there is never enough time to have a sensible stability and balance in life.

This mental stress for women lead to physical stress and cause ill health, headache, gastritis, body ache etc. or lead to long term cardiac problems, high blood pressure, diabetes or other psychiatric problems. All these problems generate Work life conflict especially for women employees, which results in:

- Increased Absenteeism

- Increased Employee Turnover

- Reduced Productivity

- Reduced Job Satisfaction

- Increased Managerial Stress

- Damage Family and Social relationship

Work life imbalance causes relationship degradation for women employees because working too much may cause women to miss family interactions as well as important events. Relationships require nurturing, time and ongoing attention. Once damage is done, it is often more difficult and time consuming to repair than if appropriate time and focus had occurred all along [9].

\section{EFFECTS OF POOR WORK LIFE BALANCE ON THE ORGNIZATION}

- Workers Punctuality, Teamwork, Customer service, work supervision responsibility, group behavior, peer interaction and leadership initiative by workers are reduced due to lowered self-worth and morale in workers due to conflict in work life balance. 
- Creativity, new job-expertise learning and innovation of worker is grossly undermined due to lowering of work related enthusiasm among workers.

- Workers having problem balancing work roles and family roles set bad standard in the company work setting and often upset the friendly work ambience.

- Workers problems get reflected negatively on company's turnover, operating profit and balance sheet.

- Substantial increase in the cases of workers being absent on the job and in extreme cases leaving the job.

\section{SOME CHALLENGES TO WORK LIFE BALANCE}

There is still however an uneven dissemination of work-family life policies among employers that causes future challenges as follows [13].

\section{1. Employers do not adequately and transparently communicate about work-life balance}

Poor communication results in lower levels of awareness. This can lead to members doubting the integrity of senior management as they feel that communication is unclear. The factors contributing to this challenge include:

- Organizational culture

- Lack of interest about changing the status quo

- Unwillingness and fear around how to manage a flood of requests if work-life balance initiatives were better communicated (risk management).

\section{2. Employers are pursuing inappropriate work-life balance arrangements}

There is a mismatch between what employers offer and what members want. The key factors contributing to this are:

- Employers take the easy route with a one-size-fits-all approach.

- Organizational size tends to restrict imagination and result in limited thinking.

\section{3. There are high levels of unmet demand for some work life balance options that go beyond the current 'family friendly' approach}

Particular demand for the opportunity to work in flexible hours and to have time off to care for children was found unmet demands. The key factors contributing to this are:

- A lack of recognition of the wants and needs of employees who have responsibilities for children.

- No clear legislation that these employees can rely on to coerces employers.

\section{4. Managers act as barriers to members achieving appropriate work-life balance}

Managerial behavior and attitudes are both influenced by and are influences on organizational culture. While research has shown that management role modeling of good work-life balance behaviors is an enabler in helping staff manage home and work. Various studies have also shown that line managers having major influence on employee satisfaction. 
The key factors contributing to this are:

- Many line managers have lack of sufficient decision-making power to grant authority and enable changes to working arrangements.

- The hierarchy and processes inherent in most large organizations mean that there are no incentives for managers to act differently or to think creatively about changing working arrangements.

\section{5. Self-esteem of Employees during the work}

Positively contributes to work-life balance. Doctors (particularly surgeons, gynecologists) don't really have a work-life balance. A large part of them have a very low time balance but a very high satisfaction balance and their self-esteem is very high. A study on gynecologists showed that their satisfaction balance was really high because of the satisfaction of creating a new life, which was compensation enough for any kind of time imbalance.

\section{FIGURE: 3}

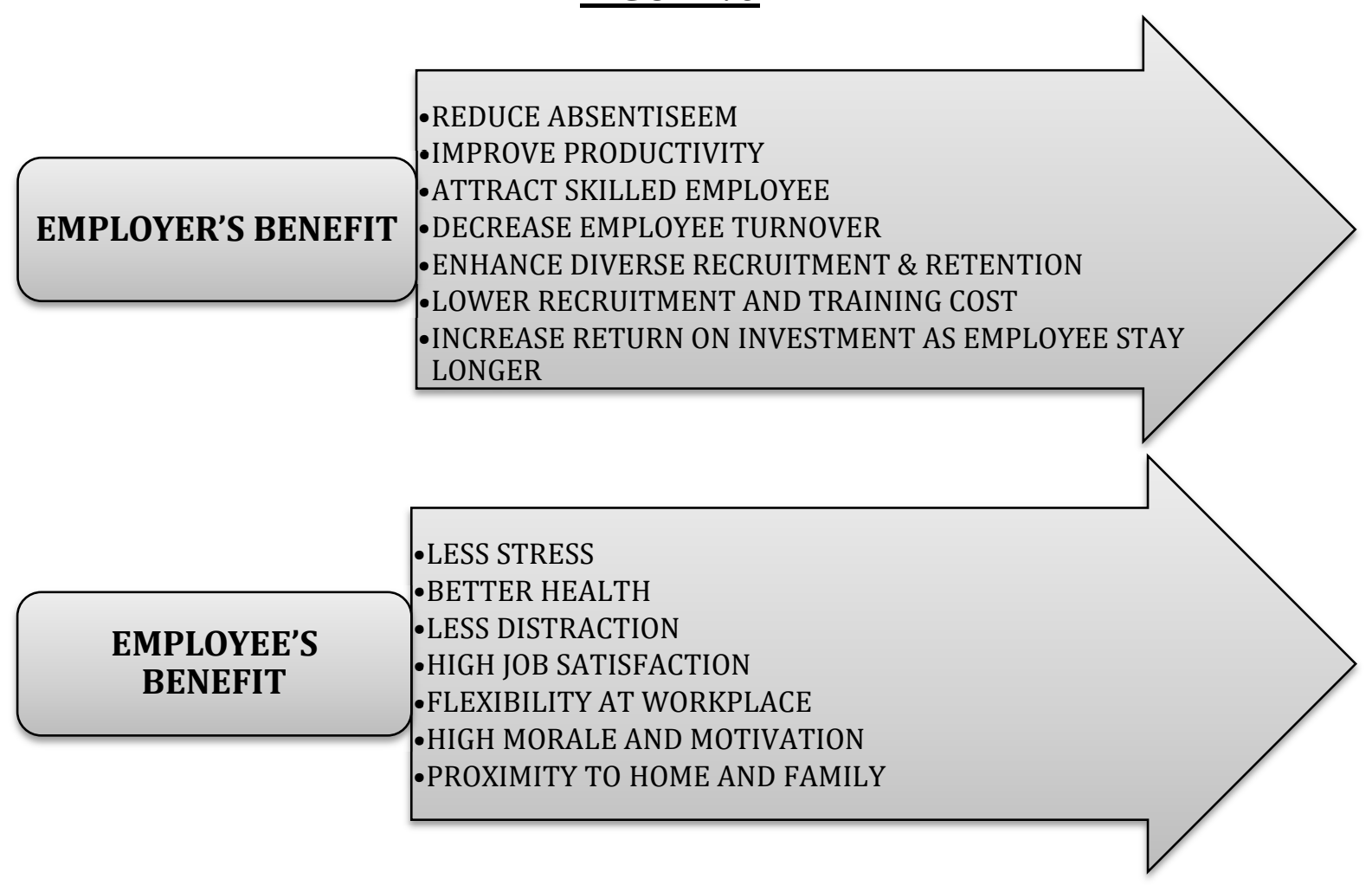

FIGURE 1: Benefits of Work Life Balance 


\section{RATIONAL OF THE STUDY}

Work-life balance is an issue of strategic importance to organizations and of significance to employees especially for women employees. Organizational awareness and action with respect to implementing work life balance strategies hinges on an Organization's need to attract and retain valued employees in a highly competitive labor market. For employees, work life balance is "the maintenance of a balance between responsibilities at work and at home". When work-life balance is achieved, people feel that they have attained the best possible quality of life.

A good work life balance is central to employee effectiveness and satisfaction, and apprentice learning work life balance is about helping staffs combine work with their personal interests and commitments. The governing body has a responsibility to ensure, so far as is reasonably practicable, the health, safety and welfare at the work of all their employees.

The objective of this research is to study the work life balance of working women in the public sector banks. It has major influence on maintaining equilibrium between professional life and the personal life responsibilities. The research was conducted among working Women in Head office of State bank of India in Bhopal city. Work life balance reduces friction between official and domestic life. The concept of balancing work and life is important in more than one way. There can be many factors affect the balance of work and life, which may be social factors, psychological factors, Working Environment, Type of job, Job satisfaction, Family background, schedule at home and life stage. The employee who is able to maintain balance between private and professional life can contribute more to success of the organization.

\section{REVIEW OF LITRETURE}

The aim of research of Sakthivel Rania, Kamalanabhanb \& Selvarania (2011) is to analyze the relationship between employee satisfaction and work/life balance. The construct used for this research consists of career opportunity, recognition, work tasks, payments, benefits, superior subordinate relationship, employee satisfaction, and work/life balance. This study makes a contribution to join two distinct research streams, namely employee satisfaction, and work/life balance. Findings suggest that high correlation exists between work task and employee satisfaction with a mediator variable namely work-life balance [11].

The objective of research of V. Varatharaj, S. Vasantha (2012) is to study the work life balance of working women in service sector. Work life balance entails attaining equilibrium between professional work and other activities, so that it reduces friction between official and domestic life. Work life balance enhances efficiency and thus, the productivity of an employee increases. It enhances satisfaction, in both the professional and personal lives. The findings of the study reveal the majority of the women Employees feel comfortable in their work place irrespective of their trivial personal and work place irritants. This paper attempts to indentify the various factor which helps to maintain work life balance among women employees in service sector [13].

The purpose of study of Babatunde Akanji (2012) is to explore the perceptions of WorkLife Balance (WLB) practices in a developing nation of Nigeria. Thus, a qualitative approach was employed by conducting 61 in-depth interviews with Nigerian employees (41 women and 20 men) working in frontline employments in the banking, telecommunications and insurance sectors about their perceptions of WLB. The findings showed that though conflict situations existed more than work-family enrichment, but under different circumstances due to the long 
legacy of national challenges facing Nigeria. This paper seeks to add to the compendium of WLB discourse on a global scale by examining key barriers detected to hinder its workable practices in Nigeria [1].

The study of Muhammadi Sabra Nadeem (2009) was aimed to explore the relationship between work life conflict and job satisfaction in Pakistan. We found that job satisfaction is significantly negatively correlated with work to family interference and family to work interference. Job satisfaction is also found to be negatively related with stress in our research. However, the correlation of workload is positive and insignificant which shows that workload does not affect the job satisfaction of the employees in Pakistan. The policy alternative should be that a supportive management is required to minimize the conflict between work and family. Top management should realize the importance of work life balance and its adverse affect on job satisfaction [10].

The research paper of Susi.S, Jawaharrani. K (2010) shows that a changing economy and an aging workforce can join together to create an employment environment where competent employees who are unhappy in their current situations are motivated to find a new place to "hang their hats". A highly engaged workforce is $50 \%$ more productive than an unengaged workforce. The majority of HR professionals (78 \%) feel employee engagement is important or extremely important to business success. Employee engagement is increasingly viewed as a "win-win" strategy for companies, employees, and their communities alike. In addition, work/life balance is increasingly important for engagement and affects retention. This paper will examine some of the literature on Employee engagement; explore work-place culture \& work-life balance policies \& practices followed in industries in order to promote employee engagement in their organizations to increase their employee's productivity and retain them [12].

The aim of the study of Lalita Kumari (2012) is to find out about the employee's perception of their work life balance policies and practices in the public sector banks. Quota sampling method was followed. Data was analyzed with the help of factor analysis, descriptive statistics, mean, t-test and Karl Pearson's correlation. The findings of the study emphasized that each of the WLB factors on its own is a salient predictor of job satisfaction and there is a significant gap among the female and male respondents with job satisfaction with respect to various factors of WLB. The result of study may have practical significance for human resource managers of especially banks to improve staff commitment and productivity along with designing their recruitment and retention policies [9].

Gururaja, Umesh Maiya, Elsa Sanatombi Devi, Anice George (2013) conducted descriptive survey among 67 nursing faculty towards their perceptions and attitude towards quality of Work-Life showed that majority, 58 (86.57\%) experienced well balanced worklife, $9(13.43 \%)$ expressed moderately balanced work -life and none of them rated under poor work-life balance. Data regarding job satisfaction showed majority 35 (52.24\%) had moderate job satisfaction and $32(47.76 \%)$ had high job satisfaction. The correlation between work life balance and job satisfaction showed positive correlation $(r=0.77)$ which can be inferred saying that high quality of work life balance will improve job satisfaction and vice versa [5].

The purpose of article of Ken Roberts (2007) is to consider why work-life balance has become a major issue, and the likely outcomes of the widespread dissatisfaction with current work schedules. Working time has not lengthened and complaints about time pressure are unrelated to hours actually worked. The sources of the widespread dissatisfaction with current work schedules will lie in a combination of other trends - increased labor market participation by women, work intensification, the spread of feelings of job insecurity, more work being done at odd hours, the spread of new information and communication technologies, free time 
increasing more slowly than spending power and aspirations, and relatively long hours becoming most common among employees (and the self-employed) in higher status jobs. An outcome is unlikely to be a general downward trend in hours worked on account of the substantial opportunity costs that would often be incurred by employees, and because some (mainly middle class) employees have access to a number of effective coping strategies [7].

The purpose of article of Joanna Hughes, Nikos Bozionelos (2007) is to explore the views of male workers in a male dominated occupation on issues that pertain to work-life balance. It emerged that work-life imbalance was not only a source of concern, but also that it was the major source of dissatisfaction for participants. Furthermore, participants made a clear connection between problems with work-life balance and withdrawal behaviors, including turnover and non-genuine sick absence [6].

\section{RESEARCH METHEDOLOGY}

The study is a descriptive study. Questionnaire is designed to collect the data from women employees of State bank of India, Bhopal city (M.P.) Head office [8].

\section{1. Objectives of the study}

- To study the working environment of public sector banks in Bhopal (from the view point of work life balance).

- To study the perception about the work life balance amongst the working women in State bank of India.

- To study the initiative taken by the organization for effective work life balance.

- To study the effects of work life balance amongst the working women in state bank of India.

\section{2. Hypothesis}

- The working environment in public sector banks is positive and healthy.

- The working women of state bank of India have positive attitude about the work life balance.

- The initiatives taken by the state bank of India have positive effect on their working women.

- There is a positive effect of work life balance on job satisfaction amongst the working women.

\section{3. Sampling plan}

- Sample Unit: Target groups [Women employees working in city head office and other selected branches of State bank of India, Bhopal (M.P.)].

- Sample Size: 100

\section{4. Research approach}

Survey (Primary data is collected through self structured questionnaire) [8]. 


\section{QUESTIONNAIRE}

1. How is the working Environment in your organization.

\begin{tabular}{|c|c|c|c|}
\hline S. NO. & OPINION & NO. & PERCENT (\%) \\
\hline 1 & Participative & 37 & 37 \\
\hline 2 & Autonomy & 19 & 19 \\
\hline 3 & Capricious & 24 & 24 \\
\hline 4 & Red Tapism & 20 & 20 \\
\hline Total & & 100 & 100 \\
\hline \multicolumn{4}{|c|}{$\chi^{2}=8.24 \quad \mathrm{df}=3, \quad \chi^{2}(.05)=7.81$} \\
\hline
\end{tabular}

When asked to the women employees working environment in SBI, then majority of $37 \%$ said participative and $19 \%, 24 \%, 20 \%$ said autonomy, capricious and red tapism consequently. The chi square value radically shows that opinion of the respondents was significantly different on asking about working environment.

2. Work allotted to you is according to your qualification and skills.

\begin{tabular}{|c|c|c|c|}
\hline S.NO. & OPINION & NO. & PERCENT (\%) \\
\hline 1 & Strongly agree & 15 & 15 \\
\hline 2 & Agree & 27 & 27 \\
\hline 3 & Disagree & 34 & 34 \\
\hline 4 & Strongly disagree & 24 & 24 \\
\hline Total & & 100 & 100 \\
\hline \multicolumn{2}{|c|}{$\chi^{2}=7.44 \quad \mathrm{df}=3, \quad \chi^{2}(.05)=7.81$}
\end{tabular}

When it is asked to the respondents that Work allotted to you is according to your qualification, $15 \%$ and $27 \%$ were strongly agree and agree respectively and said And as a group of $34 \%$ and $24 \%$ were disagree and strongly disagree correspondingly. The chi square value completely shows that the opinion of respondents was significantly identical when it comes to allotment of work according to the skills.

3. Employees are satisfied with the top Management in your organization?

\begin{tabular}{|c|c|c|c|}
\hline S.NO. & OPINION & NO. & PERCENT (\%) \\
\hline 1 & Strongly agree & 15 & 15 \\
\hline 2 & Agree & 43 & 43 \\
\hline 3 & Disagree & 31 & 31 \\
\hline 4 & Strongly disagree & 11 & 11 \\
\hline Total & & 100 & 100 \\
\hline \multicolumn{2}{|c|}{$\chi^{2}=26.24 \quad \mathrm{df}=3, \quad \chi 2(.05)=7.81$} \\
\end{tabular}


When it is asked to employees of SBI that you are satisfied with the top Management, then majority of $15 \%$ and $43 \%$ were strongly agree and agree respectively while only $31 \%$ and $11 \%$ were disagree and strongly disagree respectively. The chi square value radically shows that opinion of the respondents was significantly different.

4. Are you satisfied with the working hours of the organization?

\begin{tabular}{|c|c|c|c|}
\hline S.NO. & OPINION & NO. & PERCENT (\%) \\
\hline 1 & Highly Satisfied & 12 & 12 \\
\hline 2 & Satisfied & 34 & 34 \\
\hline 3 & Dissatisfied & 35 & 35 \\
\hline 4 & Highly Dissatisfied & 19 & 19 \\
\hline Total & & 100 & 100 \\
\hline \multicolumn{3}{|c|}{$\chi^{2}=15.44 \quad \mathrm{df}=3, \quad \chi^{2}(.05)=7.81$} \\
\end{tabular}

When it is asked to respondents that are you satisfied with the working hours, $12 \%$ and $34 \%$ highly satisfied and satisfied respectively and $35 \%$ and $19 \%$ were dissatisfied and highly dissatisfied correspondingly. The chi square value completely shows that the opinion of respondents was significantly dissimilar when it comes to working hours.

5. After working hours you get enough time for your family?

\begin{tabular}{|c|c|c|c|}
\hline S.NO. & OPINION & NO. & PERCENT (\%) \\
\hline 1 & Never & 10 & 10 \\
\hline 2 & Sometimes & 22 & 22 \\
\hline 3 & Often & 31 & 31 \\
\hline 4 & Always & 37 & 37 \\
\hline Total & & 100 & 100 \\
\hline
\end{tabular}

On asking to the women employees that you get enough time for your family after the job, then $10 \%$ and $20 \%$ said never and sometimes respectively and as a group of $31 \%$ and $37 \%$ said often and always in that order. The chi square value entirely shows that the opinion of respondent was significantly different and majority of employees is in favor that they always get the time for their family.

6. Do you feel that you are able to balance your work life?

\begin{tabular}{|c|c|c|c|}
\hline S.NO. & OPINION & NO. & PERCENT (\%) \\
\hline 1 & Strongly agree & 21 & 21 \\
\hline 2 & Agree & 34 & 34 \\
\hline 3 & Disagree & 20 & 20 \\
\hline 4 & Strongly disagree & 25 & 25 \\
\hline Total & & 100 & 100 \\
\hline \multicolumn{3}{|c|}{$\chi^{2=4.92 \quad \mathrm{df}=3,} \chi^{2(.05)=7.81}$} \\
\hline
\end{tabular}


When it is asked to the respondents that are able to balance your work life, then mass of $21 \%$ and $34 \%$ were strongly agree and agree respectively and only $20 \%$ and 25 were disagree and strongly disagree on this fact. The chi square value radically shows that the opinion of respondents was significantly similar.

7. How often do you think or worry about work (when you are not actually at work or traveling to work)?

\begin{tabular}{|c|c|c|c|}
\hline S. NO. & OPINION & NO. & PERCENT (\%) \\
\hline 1 & Never think about work & 15 & 15 \\
\hline 2 & Sometimes & 39 & 39 \\
\hline 3 & Often & 31 & 31 \\
\hline 4 & Always & 15 & 15 \\
\hline Total & & 100 & 100 \\
\hline
\end{tabular}

$$
\chi^{2}=17.28 \quad \mathrm{df}=3, \quad \chi^{2}(.05)=7.81
$$

On asking to the employees that do you get worry about work after the working hours then only $15 \%$ said that they never think about work and as a group of $39 \%$ think sometimes and $31 \%$ and $15 \%$ of respondents think often and always respectively. The chi square value clearly indicates that the opinion of respondents was significantly different.

8. Your organization takes initiative to manage work life of its employees?

\begin{tabular}{|c|c|c|c|}
\hline S.NO. & OPINION & NO. & PERCENT (\%) \\
\hline 1 & Never & 15 & 15 \\
\hline 2 & Sometimes & 30 & 30 \\
\hline 3 & Often & 44 & 44 \\
\hline 4 & Always & 11 & 11 \\
\hline Total & & 100 & 100 \\
\hline
\end{tabular}

$$
\chi^{2}=27.28 \quad \mathrm{df}=3, \quad \chi^{2}(.05)=7.81
$$

On asking to the women employee that Your organization takes initiative to manage work your life then $15 \%$ and $30 \%$ said never and sometimes correspondingly and as a group of 44 $\%$ were said that SBI often takes initiative to manage work life and only $11 \%$ respondents said always. The chi square value clearly indicates that the opinion of respondents was significantly different on current initiatives taken by SBI to manage work life. 
9. If yes what are the initiatives that your organization has taken for managing work life?

\begin{tabular}{|c|c|c|c|}
\hline S. NO. & OPINION & NO. & PERCENT (\%) \\
\hline 1 & Flexible work Timings & 38 & 38 \\
\hline 2 & Leaves to manage work life & 44 & 44 \\
\hline 3 & Job Share Option & 05 & 05 \\
\hline 4 & All of the above & 13 & 13 \\
\hline Total & & 100 & 100 \\
\hline \multicolumn{2}{|c|}{$\chi^{2}=42.96 \quad \mathrm{df}=3, \quad \chi 2(.05)=7.81$} \\
\hline
\end{tabular}

When it is asked to the respondents of SBI that what are the initiatives that your organization has taken, then $38 \%$ said flexible work timing and mass of $44 \%$ said it is leaves to manage work life and only $5 \%$ said it is job sharing option and $13 \%$ were agree that all mentioned initiatives has been given to them. The chi square value radically shows that the opinion of respondents was significantly unlike.

10. Employees have more pressure of work in the organization or it is evenly distributed?

\begin{tabular}{|c|c|c|c|}
\hline S. NO. & OPINION & NO. & PERCENT (\%) \\
\hline 1 & Have Pressure & 31 & 31 \\
\hline 2 & Evenly distributed & 39 & 39 \\
\hline 3 & Depends on the situation & 29 & 29 \\
\hline 4 & All of the above & 01 & 01 \\
\hline Total & & 100 & 100 \\
\hline \multicolumn{2}{|c|}{$\chi^{2}=32.96 \quad \mathrm{df}=3, \quad \chi^{2}(.05)=7.81$} \\
\end{tabular}

On asking to the employees that you have more pressure of work or it is evenly distributed then only $31 \%$ said that they have pressure of work and as a group of $39 \%$ said that it is evenly distributed and $29 \%$ respondents said that it depends on the situation and only $1 \%$ said all given conditions are present. The chi square value clearly indicates that the opinion of respondents was significantly different.

11. Policy for work Life Management helps to increase productivity of the organization?

\begin{tabular}{|c|c|c|c|}
\hline S. NO. & OPINION & NO. & PERCENT (\%) \\
\hline 1 & Strongly agree & 28 & 28 \\
\hline 2 & Agree & 45 & 45 \\
\hline 3 & Disagree & 15 & 15 \\
\hline 4 & Strongly disagree & 12 & 12 \\
\hline Total & & 100 & 100 \\
\hline \multicolumn{2}{|c|}{$\chi^{2}=27.12 \quad \mathrm{df}=3, \quad \chi^{2}(.05)=7.81$} \\
\hline
\end{tabular}

When it is asked to the employees that work Life Management policies help to increase productivity, then mass of $28 \%$ and $45 \%$ were strongly agree and agree respectively and said 
that it improves productivity and only $15 \%$ and $12 \%$ were disagree and strongly disagree accordingly. The chi square value completely shows that the opinion of respondents was significantly different when it comes to policies of WLB.

12. Employees are able to balance their work life due to work life management policy of the organization?

\begin{tabular}{|c|c|c|c|}
\hline S. NO. & OPINION & NO. & PERCENT (\%) \\
\hline 1 & Strongly agree & 35 & 35 \\
\hline 2 & Agree & 40 & 40 \\
\hline 3 & Disagree & 14 & 14 \\
\hline 4 & Strongly disagree & 11 & 11 \\
\hline Total & \multicolumn{2}{|c}{100} & 100 \\
\hline
\end{tabular}

On asking to the respondents that bank's policies help in balancing work life, then 35 and 40 $\%$ of them were strongly agree and agree in that order and only $14 \%$ were disagree and $11 \%$ were strongly disagree with the statement. Also chi square value depicts that the opinion of respondents was significantly different.

13. Organization is able to retain its employees due to efficient work life management policy?

\begin{tabular}{|c|c|c|c|}
\hline S. NO. & OPINION & NO. & PERCENT (\%) \\
\hline 1 & Strongly agree & 40 & 40 \\
\hline 2 & Agree & 29 & 29 \\
\hline 3 & Disagree & 21 & 21 \\
\hline 4 & Strongly disagree & 10 & 10 \\
\hline Total & & 100 & 100 \\
\hline
\end{tabular}

On asking to the employees that bank's policies are helping in employee's loyalty then crowd of $40 \%$ were strongly agree and agree in that order and said that it creates loyalty among women employees and $21 \%$ respondents were disagree and only $10 \%$ were strongly disagree about it. The chi square value clearly indicates that the opinion of respondents was significantly different.

14. Rate the Flexible Working Hours provided by the organization due to current Work Life Management Policy?

\begin{tabular}{|c|c|c|c|}
\hline S. NO. & OPINION & NO. & PERCENT (\%) \\
\hline 1 & Excellent & 24 & 24 \\
\hline 2 & Good & 31 & 31 \\
\hline 3 & Average & 30 & 30 \\
\hline 4 & Poor & 15 & 15 \\
\hline Total & & 100 & 100 \\
\hline \multicolumn{2}{|c|}{$\chi^{2}=6.48 \quad \mathrm{df}=3, \quad \chi 2(.05)=7.81$} \\
\end{tabular}


On asking for providing rating to the flexible working hours due to current policies, $24 \%$ and $31 \%$ of them rated excellent and good in that order and $30 \%$ rated average and $15 \%$ rated poor. Also chi square value depicts that the opinion of respondents was significantly identical.

15. Organization provides crèche facility for children of the employees?

\begin{tabular}{|c|c|c|c|}
\hline S. NO. & OPINION & NO. & PERCENT (\%) \\
\hline 1 & Strongly agree & 10 & 10 \\
\hline 2 & Agree & 24 & 24 \\
\hline 3 & Disagree & 44 & 44 \\
\hline 4 & Strongly disagree & 22 & 22 \\
\hline Total & & 100 & 100 \\
\hline \multicolumn{2}{|c|}{} \\
\hline
\end{tabular}

When it was asked to the employees that Organization provides crèche facility for children, only $10 \%$ were strongly agree and $24 \%$ were agree While as a group of $44 \%$ and $22 \%$ were disagree and strongly disagree respectively. The chi square value completely shows that the opinion of respondents was significantly different on this fact.

16. Your organization provides maternity and paternity leave to the employees?

\begin{tabular}{|c|c|c|c|}
\hline S. NO. & OPINION & NO. & PERCENT (\%) \\
\hline 1 & Strongly agree & 28 & 28 \\
\hline 2 & Agree & 44 & 44 \\
\hline 3 & Disagree & 15 & 15 \\
\hline 4 & Strongly disagree & 13 & 13 \\
\hline Total & & 100 & 100 \\
\hline \multicolumn{2}{|c|}{$\chi^{2}=24.56 \quad \mathrm{df}=3, \quad \chi 2(.05)=7.81$} \\
\hline
\end{tabular}

When it was asked to the employees that Your organization provides maternity and paternity leave, then $28 \%$ were strongly agree and $44 \%$ were agree While only $15 \%$ and $13 \%$ were disagree and strongly disagree respectively. The chi square value completely shows that the opinion of respondents was significantly different on this fact.

17. How do you rate the leave policy of the organization?

\begin{tabular}{|c|c|c|c|}
\hline S. NO. & OPINION & NO. & PERCENT (\%) \\
\hline 1 & Highly Satisfied & 17 & 17 \\
\hline 2 & Satisfied & 33 & 33 \\
\hline 3 & Dissatisfied & 39 & 39 \\
\hline 4 & Highly Dissatisfied & 11 & 11 \\
\hline Total & & 100 & 100 \\
\hline \multicolumn{2}{|c|}{$\chi^{2}=20.8 \quad \mathrm{df}=3, \quad \chi 2(.05)=7.81$} \\
\hline
\end{tabular}


When asked to rate the leave policy of SBI, Then $17 \%$ and $33 \%$ were highly satisfied and satisfied respectively and $39 \%$ and $11 \%$ were dissatisfied and highly dissatisfied correspondingly. The chi square value fundamentally shows that the opinion of respondents was significantly dissimilar when it comes to working hours.

18. Your organization organizes Holiday camps and picnics to manage work life and personal life?

\begin{tabular}{|c|c|c|c|}
\hline S. NO. & OPINION & NO. & PERCENT (\%) \\
\hline 1 & Strongly agree & 14 & 14 \\
\hline 2 & Agree & 33 & 33 \\
\hline 3 & Disagree & 29 & 29 \\
\hline 4 & Strongly disagree & 24 & 24 \\
\hline Total & & 100 & 100 \\
\hline \multicolumn{2}{|c|}{$\chi^{2}=8.08 \quad \mathrm{df}=3, \quad \chi^{2}(.05)=7.81$} \\
\hline
\end{tabular}

When it was asked to the employees that SBI organizes Holiday camps and picnics to manage work life and personal life, then only $14 \%$ were strongly agree and $33 \%$ were agree While the majority of $29 \%$ and $24 \%$ were disagree and strongly disagree respectively. The chi square value completely shows that the opinion of respondents was significantly different regarding this issue.

19. Do you think that you have good career prospects in the organization?

\begin{tabular}{|c|c|c|c|}
\hline S. NO. & OPINION & NO. & PERCENT (\%) \\
\hline 1 & Strongly agree & 33 & 33 \\
\hline 2 & Agree & 51 & 51 \\
\hline 3 & Disagree & 10 & 10 \\
\hline 4 & Strongly disagree & 06 & 06 \\
\hline Total & & 100 & 100 \\
\hline \multicolumn{2}{|c|}{$\chi^{2}=53.04 \quad \mathrm{df}=3, \quad \chi^{2}(.05)=7.81$} \\
\hline
\end{tabular}

On asking to the employees that do you have good career prospects in SBI, then mass of $33 \%$ and $51 \%$ of respondents were strongly agree and agree and only $10 \%$ and $6 \%$ of respondents were disagree and strongly disagree about it respectively. The chi square value radically shows that opinion of the respondents was significantly different when it comes to career growth in SBI.

20. Does the organization offers In-House Doctor facility for its employees?

\begin{tabular}{|c|c|c|c|}
\hline S. NO. & OPINION & NO. & PERCENT (\%) \\
\hline 1 & Yes & 42 & 42 \\
\hline 2 & No & 58 & 58 \\
\hline Total & & 100 & 100 \\
\hline
\end{tabular}


On asking to the employees that does the organization offers In-House Doctor facility, then only $42 \%$ said yes and as a group of $58 \%$ people said no.

The chi square value significantly shows that opinion of the respondents was significantly similar.

21. Do you think that if employees have good work-life balance then organization will be more effective and successful?

\begin{tabular}{|c|c|c|c|}
\hline S. NO. & OPINION & NO. & PERCENT (\%) \\
\hline 1 & Strongly agree & 55 & 55 \\
\hline 2 & Agree & 42 & 42 \\
\hline 3 & Disagree & 02 & 02 \\
\hline 4 & Strongly disagree & 01 & 01 \\
\hline Total & & 100 & 100 \\
\hline
\end{tabular}

When it is asked to the employees that if you have good work-life balance then organization will be more effective and successful, then $55 \%$ were strongly agree and $42 \%$ were agree with this statement and merely $2 \%$ and $1 \%$ respondents were disagree and strongly disagree simultaneously. Also the chi square value radically shows that the opinion of respondents was significantly different.

22. I feel comfortable in discussing changes to my working arrangements with my manager?

\begin{tabular}{|c|c|c|c|}
\hline S. NO. & OPINION & NO. & PERCENT (\%) \\
\hline 1 & Strongly agree & 22 & 22 \\
\hline 2 & Agree & 27 & 27 \\
\hline 3 & Disagree & 34 & 34 \\
\hline 4 & Strongly disagree & 17 & 17 \\
\hline Total & & 100 & 100 \\
\hline \multicolumn{3}{|c|}{$\chi^{2=6.32 \quad \mathrm{df}=3, \quad \chi 2(.05)=7.81}$} \\
\hline
\end{tabular}

When it was asked to the employees that are you comfortable in discussing changes to your working arrangements with your manager, then $22 \%$ were strongly agree and $27 \%$ were agree While only $34 \%$ and $17 \%$ were disagree and strongly disagree respectively. The chi square value completely shows that the opinion of respondents was significantly similar on this fact.

23. I can make choices about my current working arrangements?

\begin{tabular}{|c|c|c|c|}
\hline S. NO. & OPINION & NO. & PERCENT (\%) \\
\hline 1 & Strongly agree & 24 & 24 \\
\hline 2 & Agree & 36 & 36 \\
\hline 3 & Disagree & 21 & 21 \\
\hline 4 & Strongly disagree & 19 & 19 \\
\hline Total & & 100 & 100 \\
\hline \multicolumn{2}{|c|}{$\chi^{2}=6.96 \quad \mathrm{df}=3, \quad \chi^{2}(.05)=7.81$} \\
\end{tabular}


When it was asked to the employees that can you make choices about your current working arrangements, mass of $24 \%$ and $36 \%$ were strongly agree and agree respectively and only 21 $\%$ and $19 \%$ were disagree and strongly disagree respectively by this statement. The chi square value radically shows that the opinion of respondents was significantly identical.

24. Employees with family commitments have equal career opportunities at the workplace?

\begin{tabular}{|c|c|c|c|}
\hline S. NO. & OPINION & NO. & PERCENT (\%) \\
\hline 1 & Strongly agree & 44 & 44 \\
\hline 2 & Agree & 39 & 39 \\
\hline 3 & Disagree & 10 & 10 \\
\hline 4 & Strongly disagree & 07 & 07 \\
\hline Total & & 100 & 100 \\
\hline \multicolumn{2}{|c|}{$\chi^{2}=44.24 \quad \mathrm{df}=3, \quad \chi^{2}(.05)=7.81$} \\
\hline
\end{tabular}

On asking to the respondents employees with family commitments have equal career opportunities in SBI , then $44 \%$ and $39 \%$ of them were strongly agree and agree in that order and only $10 \%$ were disagree and $7 \%$ were strongly disagree with the statement. Also chi square value depicts that the opinion of respondents was significantly different.

25. Work-life balance options are available only to parents?

\begin{tabular}{|c|c|c|c|}
\hline S. NO. & OPINION & NO. & PERCENT (\%) \\
\hline 1 & Strongly agree & 41 & 41 \\
\hline 2 & Agree & 34 & 34 \\
\hline 3 & Disagree & 13 & 13 \\
\hline 4 & Strongly disagree & 12 & 12 \\
\hline Total & & 100 & 100 \\
\hline \multicolumn{2}{|c|}{$\chi^{2}=26 \quad \mathrm{df}=3, \quad \chi^{2(.05)=7.81}$} \\
\end{tabular}

When it was asked to the employees that Work-life balance options are available only to parents, then $41 \%$ were strongly agree and $34 \%$ were agree While only $13 \%$ and $12 \%$ were disagree and strongly disagree respectively. The chi square value completely shows that the opinion of respondents was significantly different on this fact.

26. Request to change working patterns are positively received by the manager?

\begin{tabular}{|c|c|c|c|}
\hline S. NO. & OPINION & NO. & PERCENT (\%) \\
\hline 1 & Strongly agree & 26 & 26 \\
\hline 2 & Agree & 31 & 31 \\
\hline 3 & Disagree & 30 & 30 \\
\hline 4 & Strongly disagree & 13 & 13 \\
\hline Total & & 100 & 100 \\
\hline \multicolumn{2}{|c|}{$\chi^{2}=8.24 \quad \mathrm{df}=3, \quad \chi^{2}(.05)=7.81$} \\
\end{tabular}


On asking to the respondents that your request to change working patterns are positively received by the manager, $26 \%$ and $31 \%$ of them were strongly agree and agree in that order and $30 \%$ were disagree and $13 \%$ were strongly disagree with the statement. Also chi square value depicts that the opinion of respondents was significantly different.

27. Management is committed in helping employees to achieve a good work-life balance?

\begin{tabular}{|c|c|c|c|}
\hline S. NO. & OPINION & NO. & PERCENT (\%) \\
\hline 1 & Strongly agree & 19 & 19 \\
\hline 2 & Agree & 34 & 34 \\
\hline 3 & Disagree & 28 & 28 \\
\hline 4 & Strongly disagree & 19 & 19 \\
\hline Total & & 100 & 100 \\
\hline \multicolumn{2}{|c|}{$\chi^{2}=6.48 \quad \mathrm{df}=3, \quad \chi^{2}(.05)=7.81$} \\
\end{tabular}

When it was asked to the employees that Management of SBI is committed in helping employees to achieve a good work-life balance, then $19 \%$ were strongly agree and $34 \%$ were agree While $28 \%$ and $19 \%$ were disagree and strongly disagree respectively. The chi square value completely shows that the opinion of respondents was significantly the same on management commitment.

\section{FINDINGS}

- Respondents report average level of work life balance and are generally happy with their working arrangements.

- There is a feeling that employers are investing in work-life balance, but the 'solutions' offered are not always compatible with employee's needs.

- In some cases it is found that employers are not making sufficient investment in managing the implementation of initiatives.

- Some respondents feel that they are not always making well-informed decisions about their own work-life balance.

- While some feel that their employer deliberately communicates work-life balance policies ineffectively.

- Employees are pragmatic about workable solutions; although members have views about their 'ideal' working arrangement; they are prepared to settle for different arrangements and are willing to make compromises and to balance their own needs with those of the organization, customers and other staff.

- Somewhere it is found that balancing care and work affects career progression.

- In some branches of the bank, available work-life balance options are not always appropriate.

- Somewhere employers do not adequately and transparently communicate about work-life balance.

- Work-life balance options for which there are high levels of demand are partially provided. 
- Somewhere managers act as barriers to members achieving appropriate work-life balance.

- WLB is an important determinant of intrinsic aspects of job satisfaction.

- If the employees are given freedom to choose their own work schedules; quality and productivity of the work increases. Because if this opportunity given to the employee so it will also bring to the responsibility for finishing work within specified deadline.

- Management and employee both are responsible for having work life balance.

- The research reveals that $37 \%$ of the women employees who work in the banks are always agree that they are able to manage the private life without affecting professional life.

- It is found that most of the women employees enjoy the job and feel comfortable at their work place. This might be the reason for the growth of women employees at the working place in banking sector.

- It is found that some of the employees agree that they are physically stressed in their job. And some of the employees strongly agree that they are mentally pressurized in their job.

- Employees agree that their superiors are more helpful and cooperative which may be one of the reason for women employees to balance between their private life and professional life

- The research shows that mostly women employees work in banks for financial support and remaining to face life challenges.

- High quality of work life balance will improve the job satisfaction and vice versa.

- Most of the working women found participative environment in the banks especially in State bank of India but they didn't found allotted work as per their qualification.

- Working hours are satisfactory but sometimes late working and working in evening branches in banks interrupts work life balance.

- Most of the women found good work life balance and career growth in State bank of India.

\section{CONCLUSION}

Today we see women working in almost all types of professions demonstrating that there is no gender difference in work. In fact many organizations say that women are playing a vital role in uplifting the organization. This is a positive development that women are making their presence in different walks of life. On the other hand, for every woman there is one more background to manage, which is home and personal life.

Today with increasing demands at work place, the interface between work life and personal life assumed significance which demands more attention. The pressures of the work or personal life can lead to stress. According to studies, it has been found that such situation affects person's health both physiologically and psychologically.

Therefore, it is important for employees to maintain a healthy balance between work and their private lives.

For the employers, Work-life balance of employees will be an important input in designing appropriate policies for employees to address work -life balance issues. Work-life balance initiatives should be designed to help employees to balance their work and personal life. Also our research study aims to figure out the working environment of public sector banks for women employees and what is the perception of women about the initiative and effects of those initiatives taken by the banks because Work-Life Balance is not a problem to be solved. It is an ongoing issue to be managed. 


\section{SUGGESTIONS}

- Although the female respondents agreed with banks WLB policies but they disagreed with overall WLB. So the female employees should be given the facilities like flexi time; job sharing; crèche facilities, and necessary breaks so that they feel that the organization is helping them in coordinating the family and professional life.

- In well-managed firms, the hours worked by both managerial and non-managerial staff are not significantly higher than those in badly run firms. This again confirms that working smarter not harder is the key determinant to successful management. Hence there should be well designed flexible working hours.

- WLB improve the productivity and eliminate job stress, employers can also make efforts to know the workload and job demands.

- Employer need to examine employee training, communication, reward system, coworker relationship and work environment.

- If the employees are given freedom to choose their own work schedules; quality and productivity of the work increases. Because of this opportunity given to the employee will also bring to the responsibility for finishing work within specified time.

- Nonfinancial rewards often have more impact than financial reorganization in attaining job satisfaction and managing life.

- Undertake a review of existing policies and improve current practices on flexible working arrangements.

- Ensure fairness and consistency in the way bank policies that support work-life balance are implemented.

- Consider the implications for work-life balance in relation to workloads and work outside conventional hours.

- Specific Counseling programs on Work Life Balance and Family welfare programs and family counseling programs can be conducted.

- Employees' social gathering programs and public contact programs will be the better option to reduce the mental pressure in the work place as the study reveals more mental pressure for the Women employees.

- Regular exercises, mediation and other soft skill practices can improve the emotional balance of the employees.

- More and more career and advancement opportunities should be provided to the young employees for professional as well as personal growth.

- Managerial people should feel that if they support the executives and non executives wholeheartedly the achievement of the mission of the organization be facilitated and compensation should be providing on the basis of team performance. So that no one feel jealousy with respect to WL policies.

- As it shows that different age groups have different perceptions regarding WLB, so work should be distributed according to the age and qualification. It will improve the employee's commitment and satisfaction level along with productivity and profitability.

- A supportive management is required to minimize the conflict between work and family. Top management should realize the importance of work life balance and its adverse affect on job satisfaction. 
- Manager should necessarily build familiar relationship, connection and understanding with workers.

- Bank should have formal counseling department to understand the workers work life balance problems and to help the workers to get the solution.

- Manager should undertake employee's survey periodically to understand the requirements and views of workers related to work life balance.

- Generous leave facility, both with or without pay in case of family urgency should be considered as much as possible.

- Initiate and engage discussion with workers using social media to understand their work life balance needs and aspirations.

- Make arrangement for infant / child care inside the office for working women.

- Create a work environment free of harassment \& discrimination.

- Banks should introduce job sharing option in which full-time post is split across two workers who agree on working hours decided in between them and career breaks (paid/unpaid).

- Self-rostering should be implemented in which staff nominates their preferred shifts and shifts are allocated as far as possible to fit these preferences.

\section{References}

[1] Babatunde Akanji (2012), "Realities Of Work Life Balance In Nigeria: Perceptions Of Role Conflict And Coping Beliefs", Vol. 10(2), pp. 248-263.

[2] Brough P., Holt J., Bauld R., Biggs A., Ryan C. (2008), “The ability of work-life balance policies to influence key social/organizational issues", Asia Pacific Journal of Human Resources, Vol. 46. Issue 3, pp. 261-274.

[3] Byrne U. (2005), "Work-life balance: Why are we talking about it at all", Business Information Review. Vol. 22, pp. 53-59.

[4] Dex S., Smith C. (2002), The Nature and Pattern of Family-Friendly Employment in Britain, Joseph Rowntree Foundation, Bristol: The Policy Press pg: 42.

[5] Gururaja Umesh Maiya, Elsa Sanatombi Devi, Anice George (2013), "Perceptions and Attitude towards Quality of Work-life Balance among nursing teachers", International Journal of Humanities and Social Science Invention, Volume:2, Issue: 3, pp. 52-54.

[6] Joanna Hughes, Nikos Bozionelos (2007), "Work-life balance as source of job dissatisfaction and withdrawal attitudes", Personnel Review Vol. 36, No. 1, pp. 145-154.

[7] Ken Roberts (2007), "Work-life balance - the sources of the contemporary problem and the probable outcomes", Employee Relations, Vol. 29, No. 4, pp. 334-351.

[8] Kothari C. R. (2004), "Research methodology - methods and techniques", new age international publishers, pp. 233-238.

[9] Lalita Kumari (2012), “Employees' Perception On Work Life Balance And It's Relation With Job Satisfaction In Indian Public Sector Banks”, IJEMR, Vol:2, Issue: 2, pp. 1-13. 
[10] Muhammadi Sabra Nadeem (2009), "The Impact of Work Life Conflict on Job Satisfactions of Employees in Pakistan", International Journal of Business and Management, Vol. 4, No. 5, pp. 63-83.

[11] Sakthivel Rania, Kamalanabhanb \& Selvarania (2011), "Work / Life Balance Reflections on Employee Satisfaction", Serbian Journal of Management, Vol. 6 (1), pp. $85-96$.

[12] Susi S., Jawaharrani K. (2010), "Work-Life Balance: The Key Driver Of Employee Engagement”, Asian Journal Of Management Research, Vol: 2, Issue:1, pp. 474-483.

[13] Varatharaj V., Vasantha S. (2012), "Work Life Balances A Source of Job Satisfaction - An Exploratory Study on the View of Women Employees in the Service Sector", International Journal of Multidisciplinary Research Vol.2 Issue 3, pp. 450-458. 